\title{
Effect of Round-Robin Instructional Strategy on Senior Secondary School Students' Interest in Electrochemistry in Federal Capital Territory Abuja Nigeria
}

\author{
Adigun Folaranmi $\mathbf{A}^{1 \rtimes}$ \\ Grace A. Ajagun ${ }^{2}$ \\ Madu Samuel ${ }^{3}$
}

'Senior Research Officer, Educational Research Centre, Nigerian Educational Research and Developmental Council (NERDC), Nigeria.

Email:follysan2013@gmail.com Tel:08033715124

${ }^{2}$ Deputy Director of Research, Policy and Programme Unit, Executive Secretary Office, Nigerian Educational

Research and Developmental Council (NERDC), Nigeria.

Tel: 08034537056

Senior Research Officer, Special Programme Centre, Nigerian Educational Research and Developmental Council

(NERDC) Sheda Abuja Nigeria.

Email:samuelsony2k@gmail.com Tel:08036321500



Corresponding Author

Abstract

This study examines the effect of Round-robin instructional strategy on senior secondary school student interest in electrochemistry in Federal Capital Territory Abuja Nigeria. The Sample for the Study comprised 210 (126 male and 84 female) students selected from 2 co educational Secondary Schools using probability sampling technique. The data were collected by the use of a Questionnaire tagged Electrochemistry Achievement Test (EAT) and Electrochemistry Interest Scale (EIS) designed and validated. The reliability of the EAT was determined using KuderRichardson (KR-2O) and the value $\mathrm{r}=0.75$ was obtained. The EIS was analyzed using Cronbach alpha reliability coefficient and the value $r=0.65$ was obtained. Two Research questions and two null hypotheses were formulated. Mean and standard deviation was used to analyze the research questions and t-test was used to test the hypotheses at 0.05 level of significances. The study revealed that Round-Robin instructional strategy improves student interest in electrochemistry than the conventional method and also there was no significant difference in gender on student interest in electrochemistry. Recommendations were made which includes; Chemistry teachers should adopt the use of Round-robin instructional strategy in teaching difficult concept like electrochemistry thereby improving students' interest in Chemistry. Teachers of Chemistry should also use all available instructional materials to raise students' interest and maintain it so as to improve their performance in Chemistry.

Keywords: Electrochemistry, Effect, Interest, Round-robin, Instructional strategy and school.

Citation | Adigun Folaranmi A; Grace A. Ajagun; Madu Samuel (2019). Effect of Round-Robin Instructional Strategy on Senior Secondary School Students' Interest in Electrochemistry in Federal Secondary School Students' Interest in Electrochemistry in Federal
Capital Territory Abuja Nigeria. Journal of Education and eLearning Research, 6(3): 129-134.

History:

Received: 21 March 2019

Revised: 26 April 2019

Accepted: 30 May 2019

Published: 28 August 2019

Licensed: This work is licensed under a Creative Commons

Attribution 3.0 License $(\mathrm{cc}) \mathbf{E r}$

Publisher: Asian Online Journal Publishing Group
Acknowledgement: All authors contributed to the conception and design of the study.

Funding: This study received no specific financial support.

Competing Interests: The authors declare that they have no conflict of interests.

Transparency: The authors confirm that the manuscript is an honest, accurate, and transparent account of the study was reported; that no vital features of the study have been omitted; and that any discrepancies from the study as planned have been explained.

Ethical: This study follows all ethical practices during writing.

\section{Contents}

1. Introduction

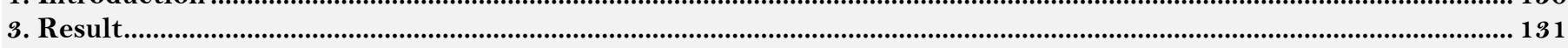

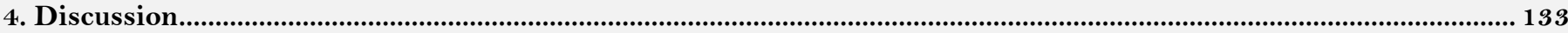

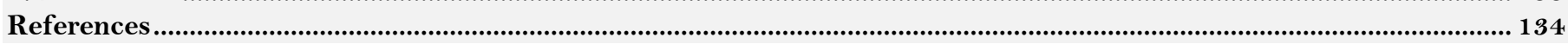




\section{Contribution of this paper to the literature}

This study contributes to the existing literature by bridging the gap as there are contradictions in the studies of students' interest in Chemistry. But this study did not found a study on Round-robin instructional strategy and students' interest in this particular concept electrochemistry in Abuja that is known to the researchers which may aid the achievement of student in Chemistry, especially in electrochemistry. No studies on Round-robin strategy were conducted in electrochemistry in Abuja but in other selected topics in Chemistry. This research intends to fill this knowledge gap and it also differs from other studies in terms of locations, target population and also the topic used in the study.

\section{Introduction}

Chemistry is the study of the structure, properties, and uses of matter. It is the science of matter and the changes it undergoes, Chemistry explains chemical process of our daily life (Kolomuç and Tekin, 2011). Aniodoh and Eze (2014) described Chemistry as a branch of science which helps learners to know what is happening around them; it affords students the privilege to examine their immediate environment. The objective of Chemistry education in schools extends to the principles of Chemistry that students have to learn and understand and the chemical procedures behind phenomena in life (Kolomuç and Tekin, 2011; Ifeyinwa and Nweze, 2014). Within the area of science education, Chemistry has been identified as a very important subject in secondary schools and the importance of Chemistry in science and technology development of the nation has been reported. It was as a result of its importance that it has been made a core-subject among the natural sciences and other science-related courses in the Nigerian education system (Akinsola and Igwe, 2002). Its inclusion as an important core subject in science in the senior secondary school (SSS) calls for the need to teach it effectively. This is because adequate and effective teaching of science can lead to the achievement of scientific and technological greatness.

In spite of the importance of Chemistry in our daily life and among other science and related subjects, it has been observed that students achievement in Chemistry at Senior Secondary School Certificate Examinations (SSSCE) has been poor and unimpressive (Njoku, 2005). Some factors have been identified as the causes of the poor achievement of students in Chemistry in Nigeria. These factors include; poor instructional strategies; difficult Chemistry concept, and the mathematical nature of Chemistry (Ayogu, 2001; Eniayeju, 2010). Most Chemistry concepts like electrochemistry in senior secondary school curriculum have proved to be difficult for students to learn as observed in the Chief Examiners Report of West African Examinations Council (2017) where the concept of electrochemistry has been described as one of the concept difficult for student to understand. According to Gongden (2016) some concepts (such as electrochemistry) are labeled difficult because students have continues to show lack of adequate knowledge, skills and strategies in solving problems and understanding the concepts. The effect is that these topics are either forbear to treat with attention or not taught properly, and students continue to perform poorly in such areas or dodged them during examinations such as WAEC, NECO and internal exams. The general poor achievement of students in the senior secondary school Chemistry examination has been of great concern to educators. It has been proved that some difficult Chemistry concepts like electrochemistry pose strong resistance to the conventional teaching methods in realizing Chemistry education objectives. This is because conventional methods may lack student to student help interaction and cooperation needed for effective teaching and learning of difficult topics in electrochemistry (Mohammad, 2011).

The concept of electrochemistry is the focus of this study. It is a concept in Chemistry that is taught at the senior secondary school level. Electrochemistry is the study of the connection or links between electricity and chemical changes (Ibole-Onyegecha, 2010). Akpoghol et al. (2016) define electrochemistry as the study of converting chemical energy to electrical energy. Electrochemistry has a number of different applications in our daily life, particularly in industry. One of the most obvious important applications is that of batteries. One of the fundamental principles of cells is that they are used to make electrical batteries that are used in electrical appliances such as torches, cell phones, cameras, hearing aids, watches, remote control, wireless game controllers, Laptops etc. And the basis of how fuel or battery works is electrochemistry which makes it important in our daily life (Fabiane et al., 2002). But, in spite this importance of electrochemistry in nature, technology development and in our daily life, many students and teachers of Chemistry consider the concept difficult to learn and understand (Doymus et al., 2010).

Low enrolment of students in Chemistry in senior secondary I (SSI) compared to other subjects like biology suggests student low interest in Chemistry as a subject. Interest and behavior of students in Chemistry classroom is related to their achievement, therefore, science interest and attitudes are learned. Papanastasiou (2001) reported in a study on Round-robin strategy that those who have a positive interest and attitude to science tend to do better in the subject area. The Oxford Learner's Dictionaries (2000) defines interest as a feeling of trying to know or learn more about something or somebody; a characteristic that raises concern or inquisitiveness that holds one's alertness or attention. Interest is an aspect of affective (emotional) domain (David and Katrien, 2011). It is a construct that has to do with one's willingness to like or dislike something; interest could rise in an individual by an action or activity that tends to meet the individual's needs (Danbata, 2009). Njoku (2009) maintains that students' interest is significantly correlated with their academic achievement in school subjects and that students' interest in difficult Chemistry concepts like electrochemistry is poor, hence lead to poor academic achievement in Chemistry. One factor for the low interest in studying electrochemistry is that surveys of students and teachers suggest that students find this concept difficult and research confirms that students' mental acceptance about problem intricacy affect their learning and performance. Several articles have raise pedantic suggestions or opinions about more adequate and effective methods of teaching electrochemistry that can help students interest; but few, if any, of these have actually been tested and adopted (Michael and Thomas, 2007).

Interest can be instilled and maintained in the classroom such as electrochemistry classroom through the use of reinforcement; making the content pertinent to the needs and desire of the learner and appropriate use of suitable instructional strategy and materials that are child-centered. Agogo et al. (2015) in a study found out that there is a significant relationship in interest in electrochemistry and the students' performance. Betul (2018) carried out a study and found out a significant difference in student interest in Chemistry. From the ongoing, students' academic 
achievement and interest in electrochemistry are at a low rate. Something must be done urgently so as to salvage the situation.

The role of gender on students' academic achievement cannot be overemphasized. Although, many scholars have argues that students' academic achievement has no effect on gender. Students' gender can affect interaction in cooperative learning when groups are not inappropriate proportion according to variables.Udousoro (2003) in a study stated that, there is no significant difference in the interest of male and female students in electrochemistry but (Jegede, 2007) found out in a study that the female students have high interest in the learning of electrochemistry in secondary schools than male students while Gardunio (2001) examine gender difference in cooperative problem-solving in gifted students in electrochemistry. Garduno found no significant differences on the interest of student in electrochemistry in gender groups. Gender as an element in science interest and achievement has created a lot of concern for science scholars or educators. These show that the issue of gender in electrochemistry achievement is not yet been resolved. Therefore the need for further study is needed. If achievement in Senior School Certificate Examination (SSCE) in Chemistry is to be enhanced, more instructional strategies are needed to be adopted by teachers to facilitate the learning of difficult concepts. Round-robin instructional strategy is among such interesting and activity-oriented instructional strategies which are not yet common in Nigerian secondary schools.

\subsection{Objectives of the Study}

The following objectives guided the study; specifically, the researcher intends to find out:

1. the effect of Round-robin instructional strategy and conventional method on the interest of student taught electrochemistry.

2. the effect of Round-robin instructional strategy on the interest of male and female students taught electrochemistry.

\subsection{Research Questions}

1. What are the mean interest scores of students taught electrochemistry using Round-robin instructional strategy and conventional method?

2. What are the mean interest scores of male and female students taught electrochemistry using Round-robin instructional strategy?

\subsection{Research Hypotheses}

$\mathrm{HO}_{1}$ There is no significant difference in the mean interest scores of students taught electrochemistry using Round-robin instructional strategy and conventional method.

$\mathrm{HO}_{2}$ There is no significant difference in the mean interest scores of male and female students taught electrochemistry using Round-robin instructional strategy.

\section{Method}

The quasi-experimental design of pre-test, post-test and control group design was adopted. This design was chosen because it allows the research to occur in its natural setting. The population of the study comprises all senior secondary school II Chemistry students (SSS2) in all co-educational government secondary schools in Federal Capital Territory (FCT) Abuja Nigeria. This is because the topic chosen for this research work is in SSS2 syllabus. The choice of co-educational secondary school is based on the fact that gender is a variable in this study. The sample for the study consists of 210 SSII Chemistry students drawn (126 male and 84 female) from two (2) coeducational SSS that is distantly located from one another within Federal Capital Territory. The two secondary schools were sampled using purposive sampling technique.

The instruments used for the study include: Electrochemistry Achievement Test (EAT) and Electrochemistry Interest Scale (EIS). The EAT test consists of 25 test items adapted from WAEC and NECO past questions as pretest and post-test respectively. EIS comprised of 30 items covering student's interest in electrochemistry and is of five-point likert scale model. The EIS was created to assess students' interest in electrochemistry before and after the treatment period to see the effects of the strategy on the interest of students in electrochemistry.

The content and face validity of the EAT and EIS were ascertained through the use of experts in Science Education Dept in the University of Abuja Nigeria who examined each item of the questionnaires and evaluated whether the instrument adequately measures the intended content areas of the study. Their observations and reports were useful guides in the review of the instrument before administration.

The reliability of the EAT was decided using Kuder-Richardson (KR-2Oand the reliability coefficient was $\mathrm{r}=$ 0.75 was obtained. Data were analysis using mean and standard deviation to answer the research questions and ttest statistics to test all the hypotheses at 0.05 significance level. The EIS was analyzed using Cronbach alpha reliability coefficient and the value $r=0.65$ was obtained. The effect size $\left(r^{2}\right)$ was also calculated.

\section{Result}

Research Question 1: What are the mean interest scores of students taught electrochemistry using Roundrobin instructional strategy and Conventional method?

Table-1. Mean and standard deviation of mean interest scores of students taught electrochemistry using round-robin instructional strategy and conventional method?

\begin{tabular}{c|c|c|c|c|c|c|c}
\hline Group & \multicolumn{3}{c|}{ Pretest } & \multicolumn{4}{c}{ Post-test } \\
\hline & N & Mean & SD & N & Mean & SD & X Gain \\
\hline Experimental & 103 & 88.68 & 2.00 & 103 & 98.92 & 1.89 & 10.24 \\
\hline Control & 107 & 66.31 & 2.78 & 107 & 70.92 & 17.63 & 4.61 \\
\hline Source: Result from fieldwork computed by the
\end{tabular}

Source: Result from fieldwork computed by the author using IBM SPSS Statistics 23 . 
Table 1 shows that the mean and standard deviation of both pre-test and post-test mean interest scores of students taught electrochemistry using Round-robin instructional strategy are 88.68 and 2.00 for pre-test, and 98.92 and 1.89 for post-test respectively while the mean and standard deviation of the students taught electrochemistry using conventional method are 66.31 and 2.78 for pre-test, and 70.92 and 17.63 for post-test respectively. The mean gain for students taught using Round-robin instructional strategy and conventional method are 10.24 and 4.61 respectively. The result indicates that students taught electrochemistry using Roundrobin instructional strategy had higher interest mean scores than their counterparts taught the same topic using conventional teaching method. The standard deviation ranges from 1.89 to 17.63 , this indicates a wide spread of scores in the groups that is, the data points are spread out over a wide range of values.

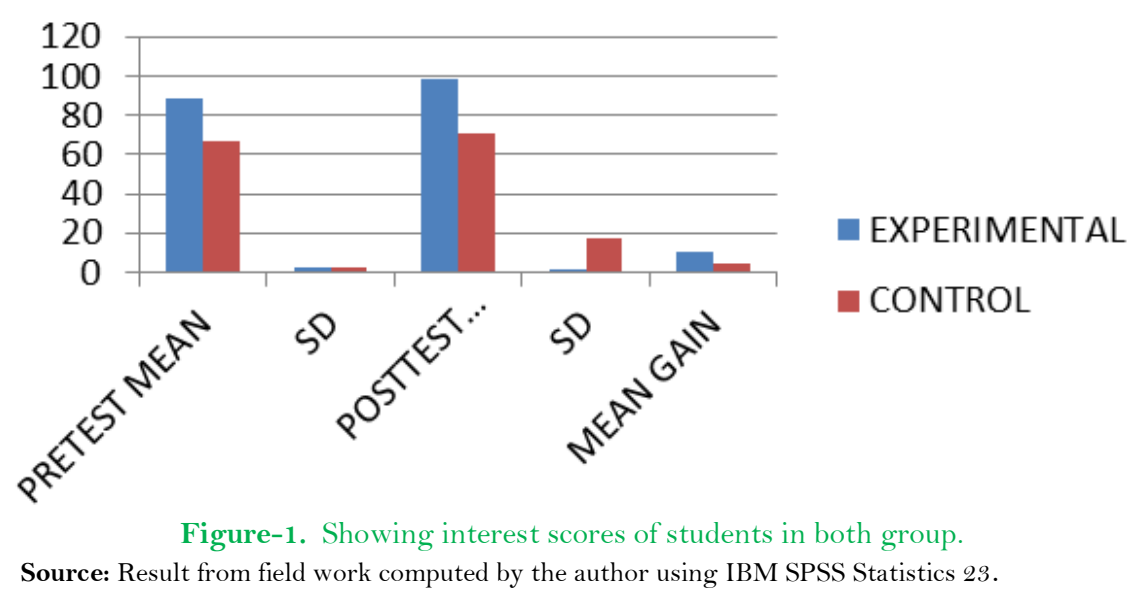

Figure 1 shows the bar chart of the mean and standard deviation of both pre-test, post-test mean and mean gain interest scores of students taught electrochemistry using both Round-robin instructional strategy and conventional method. The experimental group has a pre-test mean score of 88.68 and a standard deviation of 2.00 , while the control group has a pre-test mean score of 66.31 and a standard deviation of 2.78 . Also the experimental group has posttest mean score of 98.92 and a standard deviation of 1.89 while the control group has a posttest mean score 70.92 and standard deviation of 17.63 respectively. The mean gain for students taught using Roundrobin instructional strategy and conventional method are 10.24 and 4.61 respectively. The result on the bar chart indicates that students taught electrochemistry in the experimental group had higher interest mean gain scores than their counterparts taught the same topic control group.

\subsection{Null Hypothesis 1}

$\mathrm{HO}_{\mathrm{l}}$ : There is no significant difference in the mean interest scores of students taught electrochemistry using Round-robin instructional strategy and conventional method.

Table-2. Independent T-test analysis of interest scores of students taught electrochemistry using roundrobin instructional strategy and conventional method.

\begin{tabular}{|c|c|c|c|c|c|c|c|}
\hline Group & $\sum \mathbf{n}$ & $\overline{\mathbf{X}}$ & Sd & df & t-value & P-value & $r^{2}$ \\
\hline Experimental Group & 103 & 98.92 & 1.89 & 208 & 5.70 & .00 & 0.14 \\
\hline Control Group & 107 & 70.92 & 17.63 & & & & \\
\hline
\end{tabular}

Table 2 shows the interest mean scores of students in the control group (Mean $=70.92, \mathrm{Sd}=17.63$ ) is significantly different from those of the students in the experimental group (Mean $=98.92, \mathrm{Sd}=1.89$ ). The mean difference of 28.01 is statistically significant, $(\mathrm{t} 208=5.70, \mathrm{P}=.00)$. This shows that there is statistical difference between the experimental group and control group mean interest scores. The size or the magnitude of the effect of the treatment $\left(r^{2}=0.14\right)$ on the difference is around $14 \%$, thus, the finding has a large effect. Therefore, the null hypothesis five is rejected and concludes that there is significant difference between the interests mean scores of student taught electrochemistry using Round-robin instructional strategy and conventional method.

Research Question 2: What are the mean interest scores of male and female students taught electrochemistry using Round-robin and instructional strategy?

Table-3. Mean and standard deviation of interest scores of male and female students taught electrochemistry using roundrobin and instructional strategy?

\begin{tabular}{c|c|c|c|c|c|c|c}
\hline Gender & \multicolumn{3}{|c|}{ Pre-test } & \multicolumn{5}{c}{ Post test } \\
\hline & N & Mean & SD & N & Mean & SD & X Gain \\
\hline Male & 59 & 57.10 & 2.26 & 59 & 64.54 & 16.01 & 7.44 \\
\hline Female & 44 & 90.45 & 1.96 & 44 & 98.92 & 1.89 & 8.47 \\
\hline
\end{tabular}

Table 3 shows that male students taught electrochemistry using Round-robin instructional strategy had a pretest mean score of 57.10 with a standard deviation of 2.26, and a post-test mean score of 64.54 with a standard deviation of 16.01. While the female students had a pre-test mean score of 90.45 with standard deviation of 1.96 and a post-test mean of 98.92 with a standard deviation of 1.89 . The mean gain for both male and female students taught electrochemistry using Round-robin Instructional strategy are 7.44 and 8.47 respectively. The result of the finding shows that female students have higher interest mean score than male taught electrochemistry using Round-robin instructional strategy. The standard deviation ranges from 1.89 to 16.01, this indicates a wide spread of scores in the group. 


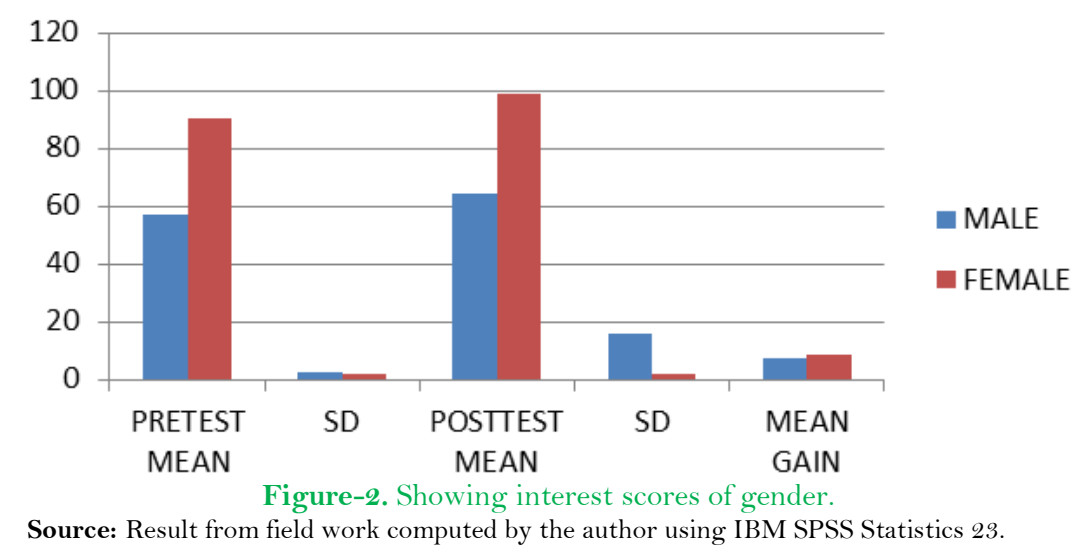

Figure 2 shows the bar chart of the performance of male and female students taught electrochemistry in the experimental group. The male students had a pretest mean score of 57.10 with a standard deviation of 2.26 , and a post-test mean score of 64.54 with a standard deviation of 16.01 . While the female students had a pre-test mean score of 90.45 with standard deviation of 1.96 and a post-test mean of 98.92 with a standard deviation of 1.89. The mean gains for both male and female students in the experimental group are 7.44 and 8.47 respectively. The result of the bar chart shows that female students have higher interest mean score with 8.47 than their male counterpart with 7.44 in the experimental group.

\subsection{Null Hypothesis 2}

HO:There is no significant difference in the mean interest scores of male and female students taught electrochemistry using Round-robin instructional strategy.

Table-4. Dependent T-test analysis the mean interest scores of male and female students taught electrochemistry using round-robin instructional strategy.

\begin{tabular}{c|c|c|c|c|c|c}
\hline Gender & $\sum \mathbf{n}$ & $\overline{\mathbf{X}}$ & $\mathbf{S d}$ & $\mathbf{d f}$ & t-value & P-value \\
\hline Male & 59 & 64.54 & 16.01 & 101 & -7.67 & .52 \\
\hline Female & 44 & 98.92 & 1.89 & & & \\
\hline
\end{tabular}

Source: Result from field work computed by the author using IBM SPSS Statistics 23.

Table 4 shows the data on the mean interest scores of male and female students taught electrochemistry using Round-robin instructional strategy. The SPSS output of the analysis shows the mean and standard deviation of male student taught electrochemistry using Round-robin instructional as 64.54 and 16.01, whereas the mean and standard deviation of female student taught the same topic using conventional method was 98.92 and 1.89. This shows that there is a difference in performance between the male and female student (mean difference $=34.38$., $\mathrm{Sd}$ $=16.01$ ).

In addition, the calculated value of $\mathrm{t}$ is -7.67 while the $\mathrm{P}$-value is 0.52 . Since the $\mathrm{P}$-value is greater than 0.05 , it means that there is less than $1 \%$ chance that the difference between the male and female students mean scores occurred by chance. Therefore, we retained the null hypothesis and conclude that there is no significant difference between the interest scores of male and female students taught electrochemistry using Round-robin instructional strategy.

\section{Discussion}

The findings of the study are discussed below;

From the test of hypothesis 1 states that there is no significant difference in the mean interest scores of students taught electrochemistry using Round-robin instructional strategy and conventional method. Table 2 shows that students taught electrochemistry using Round-robin instructional strategy have a higher interest mean score than those students taught using conventional method. The finding of the study agreed with the findings of Agogo et al. (2015) and Betul (2018) who revealed that there is significant difference on student interest in electrochemistry.

Hypothesis 2 states that there is no significant difference in the mean interest scores of male and female students taught electrochemistry using Round-robin instructional strategy. The results of the analysis on Table 3 indicate that both male and female students show interest in electrochemistry using Round-robin instructional strategy. Thus, there is no statistically significant difference in the mean interest scores of male and female students taught electrochemistry using Round-robin instructional strategy. The finding of the study agreed with the findings of Udousoro (2003) and Gardunio (2001) who revealed that there is no significant difference on the interest of male and female students in electrochemistry.

\subsection{Conclusion}

Based on the finding of the study, it is concluded that: Round-robin instructional strategy was found to enhancing students' interest in electrochemistry than the conventional method and both male and female students improved in their interest rate when they were taught electrochemistry using Round-robin instructional strategy.

\subsection{Recommendations}

It is therefore recommended that:

1. Teachers of Chemistry should adopt Round-robin instructional strategy in teaching electrochemistry thereby improving achievement in Chemistry. 
2. Teachers of Chemistry should use all available instructional materials to raise students' interest and maintain it so as to improve their performance in Chemistry.

3. Ministry of Education should organize Seminars, conferences and workshops on modern instructional strategies like Round-robin instructional strategy at all levels (Local, State and Federal) for Chemistry teachers, curriculum planners, school administrators, authors Chemistry of textbooks and the various external examination.

\section{References}

Agogo, P.S., C. Odoh and B. Simon, 2015. Interest and sustenance as correlates of students' performance in senior secondary Chemistry in Ogbadibo local government area of Benue State, Nigeria. Global Educational Research Journal, 2(5): 55-60.

Akinsola, M. and I. Igwe, 2002. The relative effect of metacognitive strategy of framing on students achievement in selected difficult chemistry concepts. Journal of the Science Teachers Association of Nigeria, 37(1): 20-27.

Akpoghol, T.V., F. Ezeudu, J. Adzape and E. Otor, 2016. Effects of lecture method supplemented with music and computer animation on senior secondary school students' academic achievement in electrochemistry. Journal of Education and Practice, 7(4): 75-86.

Aniodoh, H.C.O. and G.N. Eze, 2014. Achieving effectiveness in secondary school Chemistry classrooms using constructive approach: A case study of physical and chemical. Annual Conference of Science Teachers Association of Nigeria. Delta 18th - 23rd August pp: 247252.

Ayogu, Z.U., 2001. Enriching science, technical and mathematics education. 41st National Conference Proceedings of the Science Teachers Association of Nigeria. Port-Harcourt pp: 396 - 399.

Betul, 2018. Turkish students' (age 15 or older) interest in Chemistry by analysing 1027 of their elf-generated Chemistry-related questions. Journal of Chemistry Education Research and Practice, 15(2): 192-206.

Danbata, 2009. Interest and effort in education. Cambridge, MA: Riverside Press.

David, A.M. and J.V.D.H.K. Katrien, 2011. Affective domain and student learning in the geosciences. Journal of Geoscience Education, 59(3): 106-1 10.Available at: https://doi.org/10.5408/1.3604828.

Doymus, K., A. Karacop and U. Simsek, 2010. Effects of jigsaw and animation techniques on students' understanding of concepts and subjects in electrochemistry. Educational Technology Research and Development, 58(6): 671-691.Available at: https://doi.org/10.1007/s1 1423-010-9157-2.

Eniayeju, D., 2010. Competencies required of science education teachers. A Paper Presented at the 24th Annual Conference of the Science Teachers Association of Nigeria.

Fabiane, C.D., A.D. Patricia and O.F.G. Marilia, 2002. Some applications of electrochemistry in biomedical Chemistry. Emphasis on the correlation of electrochemical and bioactive properties. Journal of the Brazilian Chemical Society, 13(1): 57-64.

Gardunio, E.L.H., 2001. The influence of cooperative problem solving on gender differences in achievement, self-efficacy, and attitudes toward Mathematics in gifted students. Gifted Child Quarterly, 45(4): 268-282.Available at: https://doi.org/10.1177/001698620104500405.

Gongden, E., 2016. The effects of analogy on male and female Chemistry students'. Problem-solving ability in electrolysis. International Journal of Scientific Research in Education, 9(1): 1-6.

Ibole-Onyegecha, P.M., 2010. Introductory lesson on electrochemistry. In Amadi, E.O \& Ojokuku,G.O (Ed.), Teaching electrochemistry. A Handbook for Chemistry Teachers, Chemistry Panel Series 6, Science Teachers Association of Nigeria.

Ifeyinwa, G.L. and B.N. Nweze, 2014. Creativity in chemistry teaching: Effect of E-learning on students' achievement in acids, bases and salts. STEM education and creativity. 55th Annual Conference of Science Teachers Association of Nigeria, pp: $253-263$.

Jegede, S., 2007. Students anxiety towards the learning of Chemistry in some Nigerian secondary schools. Educational Research and Reviews, 2(7): 193-197.

Kolomuç, A. and S. Tekin, 2011. Chemistry teachers' misconceptions concerning concept of chemical reaction rate. Eurasian Journal of Physics and Chemistry Education, 3(2): 84-101.

Michael, J.S. and J.G. Thomas, 2007. Students' misconceptions in electrochemistry regarding current flow in electrolyte solutions and the salt bridge. Journal of Chemical Education, 74(7): 873-878.

Mohammad, N., 2011. An experimental study on the effectiveness of problem-based versus lecture-based instructional strategy on achievement, retention and problem solving capabilities in secondary schools general science students. Pakistan Research Repository E-Prints School of Electronic and Computer Science, University of Southampton.

Njoku, Z.C., 2005. Level of chemistry practical science skills acquired by senior secondary school (SSII) students. Nigeria Journal of Professional Teachers, 1(1): 88-93.

Njoku, Z.C., 2009. Enhancing the relevance of chemistry curriculum delivery using science-technology-society (STS) approach. International Council of Associations for Science Education, pp: 48-54.

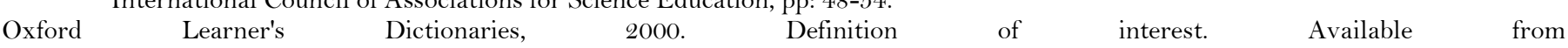
https://www.oxfordlearnersdictionaries.com/definition/english/interest_1.

Papanastasiou, E., 2001. Willingness to follow math-related careers among seniors in math classes: The case of cyprus. Science Education International, 13(2): 20-21.

Udousoro, U.J., 2003. Gender difference in computing participation: The case of University of Uyo. International Journal of Educational Development, 2(1): 190-199.

West African Examinations Council, 2017. Chief examiners' reports for May/June WASSCE. Lagos: WAEC. 